\title{
Primary immunodeficiency in Africa - a review
}

\author{
A Erjaee, ${ }^{1,2} \mathrm{MD}$; M Bagherpour, ${ }^{1,3} \mathrm{PhD} ; \mathrm{C}$ van Rooyen, ${ }^{4,5} \mathrm{MB}$ ChB, MMed (Path) (Virol), FRCPath (Virol); \\ S van den Berg, ${ }^{4,5}$ MB ChB, DTM\&H, FRCPath (Clin Path), MMed (Clin Path); C J Kinnear, ${ }^{6} \mathrm{PhD} ; \mathbf{R}$ J Green, ${ }^{5} \mathrm{PhD}, \mathrm{DSc}$; \\ M S Pepper, ${ }^{1} \mathrm{MB} \mathrm{ChB}, \mathrm{PhD}, \mathrm{MD}$ \\ ${ }^{1}$ Department of Immunology, Institute for Cellular and Molecular Medicine and SAMRC Extramural Unit for Stem Cell Research and Therapy, \\ Faculty of Health Sciences, University of Pretoria, South Africa \\ ${ }^{2}$ Department of Pediatrics, Shiraz University of Medical Sciences, Shiraz, Iran \\ ${ }^{3}$ Department of Industrial Engineering, Iran University of Science and Technology, Tehran, Iran \\ ${ }^{4}$ Department of Immunology, Ampath Pathology National Reference Laboratory, Pretoria, South Africa \\ ${ }^{5}$ Department of Paediatrics and Child Health, Steve Biko Academic Hospital and Faculty of Health Sciences, University of Pretoria, South Africa \\ ${ }^{6}$ DST-NRF Centre of Excellence for Biomedical Tuberculosis Research, South African Medical Research Council Centre for Tuberculosis Research, \\ Division of Molecular Biology and Human Genetics, Faculty of Medicine and Health Sciences, Stellenbosch University, Cape Town, South Africa
}

Corresponding author: M S Pepper (michael.pepper@up.ac.za)

\begin{abstract}
Background. Efforts have been made worldwide to improve awareness and treatment of primary immunodeficiency (PID). This has also gained momentum on the African continent albeit at a slower pace.

Objective. This review reports on the current status of PID on the African continent regarding its prevalence, distribution, genetic mutations and challenges in diagnosis and treatment of affected patients.

Method. We evaluated all studies published from the African continent in the field of PID dealing with prevalence, epidemiology, case reports and genetic findings.

Results. The prevalence of PID on the African continent has been estimated to be as high as 902631 individuals. PID still is mostly underdiagnosed in Africa and although progress has been made in parts of the continent many challenges still remain regarding awareness, diagnosis, registration and care of these patients.

Conclusion. Given the unique genetic mutations reported in PID patients on the African continent and the feasibility of hematopoietic stem cell transplantation and gene therapy, increased awareness should be encouraged and new therapeutic options considered.
\end{abstract}

S Afr Med J 2019;109(8 Suppl 1):S4-S12. https://doi.org/10.7196/SAMJ.2019.v109i8b.13820

Primary immunodeficiency disease (PID) comprises a genetically heterogeneous group of disorders caused by defects in components of the immune system. PIDs affect different components of the innate and adaptive immune systems, including neutrophils, macrophages, dendritic cells, complement proteins, natural killer (NK) cells, and T- and B-lymphocytes. ${ }^{[12]}$

\section{Classification}

Most PIDs are caused by mutations in single genes but the variable penetrance of these mutations results in diverse phenotypes and severity, which makes recognition and differential diagnosis difficult. ${ }^{[3,4]}$ Owing to this complexity, the International Union of Immunological Societies (IUIS) Expert Committee on Primary Immunodeficiency has developed a classification for PID with the goal of facilitating diagnosis and treatment. According to the last updated report in 2015, PIDs are categorised into nine major groups (Table 1). ${ }^{[5]}$

\section{Clinical manifestations}

Individuals suffering from PIDs are more prone to recurrent and chronic infections with a number of different infectious agents, which cause significant morbidity and mortality. Although impairment of immune function can affect various organs, the most common sites of infection are the sinopulmonary system and the gastrointestinal tract. While unusual organisms generally cause these infections, typical infections that are atypical in length and severity are more often observed and may lead to lethal outcomes. In addition to susceptibility to infections, a poorly regulated immune system in PID patients may lead to inflammation, autoimmunity and malignancy. ${ }^{[2]}$

\section{Global prevalence of PID}

While PIDs are individually quite rare, collectively they represent a significant burden of disease. Recent studies which have extrapolated the prevalence of PID from registry data have shown that the disease may be more common than previously estimated ${ }^{[6-10]}$ and, in fact, it has been suggested that the prevalence and incidence of PIDs may be as high as those observed for diseases such as leukaemia. ${ }^{[6]}$

To estimate the global prevalence of PID in 2013, Bousfiha et al. ${ }^{[6]}$ used data from continental and national registries in specific records from the Australia/New Zealand registry ${ }^{[7]}$ and two specific epidemiological surveys conducted in the USA. ${ }^{[8,9]}$ The prevalence of PIDs in different countries was extrapolated from these registries and surveys based on the populations of each country. It is estimated that as many as 6 million people may be living with a PID worldwide, ${ }^{[6]}$ whereas only $27000-60000(0.45-1 \%)$ have been registered in national registries and the Jeffrey Modell Centers Network (JMCN). Table 2 illustrates the frequency of PID worldwide as estimated in the Bousfiha et al.$^{[6]}$ study.

In an attempt to report all PID cases diagnosed worldwide since 2013, the Jeffrey Modell Foundation (JMF) has launched an annual survey in 358 institutions within the JMCN, covering 86 countries on 6 continents. In its latest report in 2018, JMF indicated that 187988 PID patients were being followed globally. A total of 94024 were identified as having a specific named PID. ${ }^{[10]}$ According 
Table 1. Classification of PID from the IUIS Expert Committee for Primary Immunodeficiency ${ }^{[5]}$

1 Immunodeficiencies affecting cellular and humoral immunity (e.g. SCID)

2 Combined immunodeficiency with Associated or Syndromic Features (e.g. WAS, ataxia-telangiectasia)

3 Predominantly antibody deficiencies (e.g. agammaglobunaemia)

4 Diseases of immune dysregulation (e.g. Chediak-Higashi syndrome)

5 Congenital defects of phagocyte number function or both (e.g. LAD1)

6 Defects in intrinsic and innate immunity (e.g. MSMD)

7 Autoinflammatory disorders (e.g. familial Mediterranean fever)

8 Complement deficiencies (e.g. complement cascade component deficiencies)

9 Phenocopies of PID (e.g. autoimmune lymphoproliferative syndrome)

PID = primary immunodeficiency; SCID = severe combined immunodeficiency; WAS = Wiskott-Aldrich syndrome; LAD1 = leukocyte adhesion deficiency type 1; MSMD = Mendelian susceptibility to mycobacterial disease.

Table 2. Worldwide frequency of PID estimated by Boushifa et al. ${ }^{[6]}$

\begin{tabular}{|c|c|c|c|c|}
\hline Region & $\begin{array}{l}\text { Estimate of the } \\
\text { number of PID } \\
\text { patients based on a prevalence of } \\
5.6 / 100000 \text { inhabitants from the } \\
\text { Australian Registry }{ }^{[7]}\end{array}$ & $\begin{array}{l}\text { Estimate of the } \\
\text { number of PID } \\
\text { patients based on a prevalence of } \\
86.3 / 100000 \text { inhabitants from the } \\
\text { Boyle and Buckley's survey }{ }^{[8]}\end{array}$ & $\begin{array}{l}\text { Estimate of the annual incidence } \\
\text { of PID based on an incidence of } \\
10.3 / 100000 \text { person years from } \\
\text { Joshi et al. }{ }^{[9]}\end{array}$ & Registry \\
\hline Europe & 41401 & 638015 & 76148 & $18392^{*}$ \\
\hline Africa & 58572 & 902631 & 107730 & $1306^{+}$ \\
\hline North America & 19464 & 299947 & 35799 & $2804^{\ddagger}$ \\
\hline South America & 22214 & 342336 & 40858 & 3321 \\
\hline Asia & 235617 & 3631027 & 433367 & $3841^{5}$ \\
\hline Oceania & 2082 & 32082 & 3829 & $1209^{9}$ \\
\hline Worldwide & 390546 & 6018593 & 718326 & $60364^{\|}$ \\
\hline \multicolumn{5}{|c|}{$\begin{array}{l}\text { PID = primary immunodeficiency. } \\
\text { "Europe. } \\
\text { 'North Africa. } \\
\text { "USA. } \\
\text { SJapan and Iran. } \\
\text { 'Australia and New Zealand. } \\
\text { "2011 JMF registries. }\end{array}$} \\
\hline
\end{tabular}

to this report, the subgroup 'predominantly antibody deficiencies' comprising $45 \%$ of the PID patients identified is the leading global PID followed by 'combined immunodeficiency with associated or syndromic features' in $13 \%$ of patients. This study also showed that some PIDs are more common in certain geographic areas than others. ${ }^{[10]}$

As seen above, different studies have generated inconsistent results. Moreover, worldwide data registries are not able to provide full coverage of PID patients at the present time. Therefore, the identification of PID patients is confronted by an underreporting bias. Regardless of these challenges, PIDs are clearly more common than generally thought.

\section{Diagnosis}

There is a lack of awareness of PIDs among the public and healthcare workers, resulting in delays in diagnosis. On the other hand, an important issue affecting patient outcomes is the time interval between the onset of symptoms and making a diagnosis. Therefore, early diagnosis is critical to prevent significant morbidity and mortality. In order to raise the index of suspicion among healthcare professionals and patients, the medical advisory board of the JMF identified 10 warning signs of PID (http://www.info4pi.org/aboutPI/ pdf/General10WarningSignsFINAL.pdf) (Table 3). Knowing these warning signs helps physicians to identify patients suitable for appropriate immunological evaluation. ${ }^{[2,14]}$ The IUIS PID expert committee has also recently developed a phenotypic classification, which through nine algorithms helps clinicians with bedside diagnosis of PIDs. ${ }^{[15]}$ Once an immunodeficiency is suspected, a thorough history and physical examination will further direct the

\begin{tabular}{ll} 
Table & 3. Ten warning signs of a PID in children \\
\hline 1 & $>4$ ear infections in one year \\
2 & $>2$ severe sinus infections in one year \\
3 & $>2$ months of antibiotic treatment with little effect \\
4 & $>2$ pneumonias per year \\
5 & Insufficient weight gain or growth delay \\
6 & Recurrent deep skin or organ abscesses (e.g. liver, lungs) \\
7 & Persistent thrush in mouth or fungal infection on skin \\
8 & Need for intravenous antibiotics to clear infections \\
9 & $>2$ deep seated infections (e.g. septicaemia, meningitis) \\
10 & Family history of a PID \\
PID = primary immunodeficiency.
\end{tabular}

initial workup for screening of the immune system. If the result of the initial evaluation is positive, further testing will be done. The definite diagnosis of a PID which is important for the management of patients and further genetic counseling is reached by molecular diagnosis. ${ }^{[16]}$ However, despite scientific progress in the field, there are still inadequate laboratory resources and diagnostic methods in many countries. ${ }^{[17]}$ In fact, variations observed in the number of cases reported from country to country could often be related to the lack of access to appropriate laboratory testing. ${ }^{[18]}$

\section{Treatment}

Most PIDs are chronic diseases and, once recognised, patients require specific care for the rest of their lives. However, the treatment of PID is complex and generally requires both supportive and definitive 
approaches carried out by a multidisciplinary team. Initial therapy for most patients is supportive and involves aggressive management of the infection, immunoglobulin (Ig) replacement therapy, and antibiotic and antifungal prophylaxis. Ig replacement therapy has proven to increase the survival rates and decrease the frequency of life-threatening infections, especially pneumonia in antibodydeficient patients. ${ }^{[20-22]}$ According to the 2018 JMF survey, 23967 patients were receiving Ig therapy worldwide. ${ }^{[10]}$ While cytokine- and enzyme-replacement therapy are other treatment modalities for some of these patients, haematopoietic stem cell transplantation (HSCT) and gene therapy could be considered as the definitive cure for a group of more severe PIDs, such as severe combined immunodeficiency (SCID). ${ }^{[19,23,24]}$

An allogeneic HSCT involves the intravenous infusion of allogeneic haematopoietic stem cells into the recipient's body usually after preparation of the recipient with a conditioning regimen, which permits some degree of donor cell engraftment and replacement of lymphohaematopoietic function. ${ }^{[2]}$ This procedure was first performed in 1968 on a 22 -month-old male infant suffering from SCID. ${ }^{[25]}$ In the past 45 years, there have been great advances in the field of HSCT. ${ }^{[26]}$ The remarkable improvements in allogeneic HSCT, despite the limitations of HSCT, e.g. the lack of human leukocyte antigen (HLA)-compatible donors and also complications such as graft-versus-host disease (GVHD), have increased interest in gene therapy for treating PID patients. ${ }^{[19]}$

Gene therapy was first introduced in the early 1990 s. $^{[28,29]}$ In this approach, a normal copy of the mutated and disease-related gene of the PID patient is introduced into the patient's stem cells ex vivo using a viral vector, following which the transduced cells are transplanted back into the patient's body. ${ }^{[19]}$ Given the fact that disease-related genes have now been found for most PIDs, gene therapy may become an important treatment option for many of these conditions. However, gene therapy runs the risk of insertional mutagenesis which is dependent on the nature of the technology used, such as gene editing and the type of vector. ${ }^{[31]}$ In 2018, the JMF reported on the total number of patients worldwide who had received HSCT or gene therapy: 4421 and 181 patients, respectively. ${ }^{[10]}$

\section{Methodology}

In this review, we evaluated all studies published from the African continent in the field of PID regarding prevalence, epidemiology, case reports and genetic findings. To this end, we performed a literature search in PubMed using the keywords 'prevalence, 'incidence', 'primary immunodeficiency', 'genetic mutations' and 'Africa'. We excluded studies on immunodeficiency due to human immunodeficiency virus (HIV) by using the keyword 'not HIV'. In our search we had no filter regarding the year of publication of the articles. We identified many African studies on different aspects of PID from the northern and southern regions of the continent. We found only one study from western Africa but no studies from eastern or central Africa. However, it should be cautioned that findings from northern and southern Africa cannot necessarily be extrapolated to other regions on the African continent.

\section{Results}

When compared with other continents, Africa has experienced a delay with regard to PID diagnosis and care. However, with the establishment of the African Society for Immunodeficiencies (ASID; www.asid.ma) in Casablanca (Morocco) in 2008, there has been an increase in awareness on the continent of PIDs among physicians and the general public. Moreover, ASID has begun to collect data from PID patients for the purpose of creating an international registry.
In recent years, different regions of the African continent have also been involved in hosting international congresses and workshops on PID and collaborating with experts from various parts of the world. ${ }^{[32]}$ In fact, the regions of North Africa and the Middle East have joined efforts by hosting 'The Middle East and North Africa Immunodeficiency' (MENAID) meetings; it is hoped that this will help to improve the quality of life of patients with PID. What both regions have in common is their high prevalence of consanguineous marriages $(20-60 \%)$ which results in a higher incidence of autosomal recessive PIDs. ${ }^{[32,33]}$ Another example of a medical society in Africa that is driving the dissemination of medical information and influencing public opinion is the 'Primary Immunodeficiency Diseases South Africa' working group, which is an active Working Group of the Allergy Society of South Africa (ALLSA) and hosts annual congresses and meetings (www.allergysa.org).

\section{Prevalence of PID on the African continent}

Very few studies have been conducted in Africa which specifically describe the prevalence and epidemiological features of PIDs on the continent. Those that have been conducted are shown in Table $4 .{ }^{[35-40]}$ In the latest JMF global survey, 1836 patients with PIDs out of a global total of 94024 were from Africa. ${ }^{[10]}$ Africa is the second most populous continent, suggesting that it should have a larger number of PID cases, yet its registry contains the smallest proportion of cases. Bousfiha et al ${ }^{[6]}$ estimated the prevalence of PID to be 902631 cases in Africa. The exact prevalence of PID on the African continent remains unknown.

Barbouche et al. ${ }^{[33]}$ investigated the prevalence of PID in northern Africa by collecting data from PID referral clinics in Morocco, Egypt and Tunisia and found that the most prevalent immunodeficiency reported from Egypt and Tunisia was combined immunodeficiency $(41 \%$ v. $27 \%)$, while that from Morocco was combined immunodeficiency with associated or syndromic features (34\%). The authors concluded that the hallmark of their North African PID cohort was the high rate of autosomal recessive PIDs compared with the European Registry which is aligned with the high frequency of parental consanguinity in the region.

\section{Novel mutations in the African population}

Many studies in the northern region of Africa describe an autosomal recessive transmission mode for PIDs and some have reported novel autosomal recessive gene mutations. ${ }^{[41-60]}$ Due to this fact, the northern region of Africa seems to be a distinctive epidemiological area for the study of genetic diseases, such as PIDs, which has drawn the attention of many researchers in the past decade. Table 5 illustrates some of the studies describing molecular characterisation, novel genetic mutations and founder effects of PIDs undertaken mainly in Africa.

Autosomal recessive PIDs are particularly frequent in North African populations, and a strong founder effect for specific mutations in PIDs has been reported. For example, the major histocompatibility complex (MHC) class II combined immunodeficiency has been described mainly in patients living in or originating from North African countries (predominantly the Maghrebian countries, i.e. Morocco, Algeria and Tunisia). Therefore, it has been considered to be a 'Maghrebian disease'. In fact, several studies have reported a founder effect for the RFXANK gene mutation 752delG26 in these patients. ${ }^{[46,48,49,55,59]}$ In 2011, Ouederni et al ${ }^{[55]}$ dated the founder event responsible for this mutation in this population to $\sim 2250$ years ago. A study by Ben-Mustapha et al. ${ }^{[44]}$ in 2014 reported a common founder 


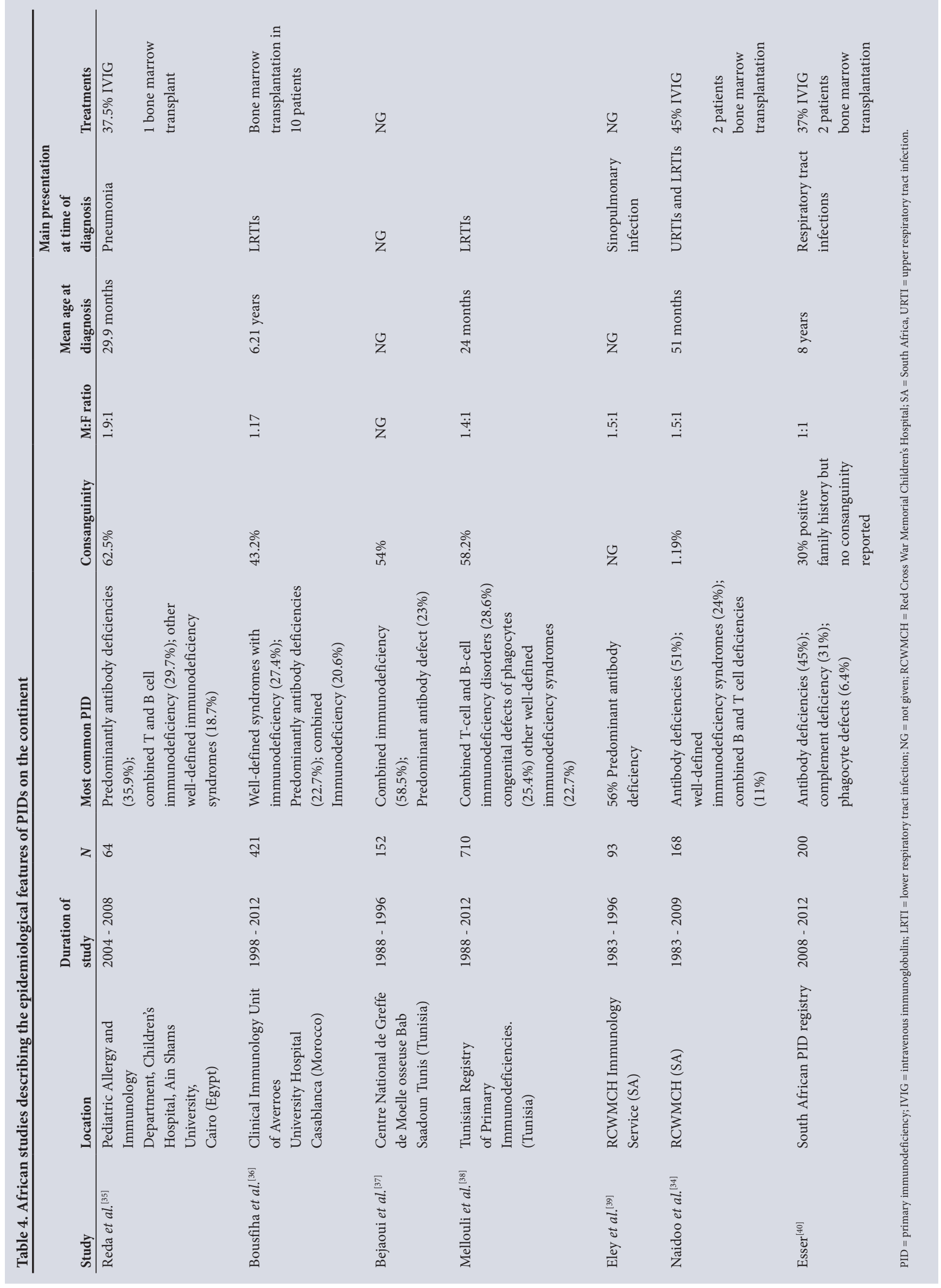




\section{Table 5. Genetic studies on PID in Africa and elsewhere}

\begin{tabular}{|c|c|c|c|c|}
\hline Study & $\begin{array}{l}\text { Country } \\
\text { where } \\
\text { study was } \\
\text { undertaken }\end{array}$ & $\begin{array}{l}\text { Patient number and } \\
\text { origin }\end{array}$ & PID studied & Genetic findings \\
\hline \multicolumn{5}{|l|}{ Studies indigenous to Africa } \\
\hline Glanzmann et al..$^{[71]}$ (2018) & SA & 1 SA family & MSMD & $\begin{array}{l}\text { De novo heterozygous } \\
4 \text { bp deletion in exon } 6 \text { of } I F N-\gamma R 1 \text { at } \\
\text { nucleotide } 818 \text { (818del } 4)\end{array}$ \\
\hline Glanzmann et al..$^{[72]}$ (2017) & SA & 1 SA family & $\begin{array}{l}\text { Aicardi-Goutières } \\
\text { syndrome }\end{array}$ & $\begin{array}{l}\text { Homozygous c.1681_1682delAG; } \mathrm{p} \text {. } \\
\text { Ser } 561 \mathrm{Phefs}^{*} 61 \text { mutation in exon } 15 \text { of } \\
\text { SAMHD1 }\end{array}$ \\
\hline Schlechter et al. ${ }^{[73]}(2017)$ & SA & 1 SA family & $\begin{array}{l}\text { Recessive atypical combined } \\
\text { immunodeficiency }\end{array}$ & $\begin{array}{l}\text { Homozygous c.G1033A p.Val345Met } \\
\text { nucleotide variant situated in exon } 5 \text { of } \\
\text { MAP3K14 }\end{array}$ \\
\hline Kinnear et al. ${ }^{[74]}(2017)$ & SA & 1 Somalian family & THE-S & $\begin{array}{l}\text { Homozygous mutation }(c .4507 \mathrm{C}>\mathrm{T} \\
\text { rs200067423) in TTC } 37\end{array}$ \\
\hline Glanzmann et al..$^{[75]}(2017)$ & SA & 1 SA family & $\begin{array}{l}\text { Immunodeficiency with } \\
\text { autoimmunity }\end{array}$ & $\begin{array}{l}\text { Compound heterozygous variant in } \\
\text { LRBA (NM_006726) (c } 3296 \mathrm{C}>\mathrm{G} \text { and } \\
\text { c. } 3407 \mathrm{C}>\mathrm{T}) \text {. }\end{array}$ \\
\hline Owen $^{[41]}(2015)$ & SA & 7 SA families & Complement deficiency & $\begin{array}{l}\text { Complement } C 5 \text { gene mutation } \\
\text { c. } 754 \mathrm{G}>\mathrm{A} \text { :p.A252T; common in the } \\
\text { Western Cape }\end{array}$ \\
\hline Jlajla $^{[42]}(2014)$ & Tunisia & 1 Tunisian family & C1q deficiency & Novel g.5580G4C mutation \\
\hline Sassi et al. ${ }^{[43]}(2014)$ & Tunisia & $\begin{array}{l}6 \text { patients } \\
\text { from } 2 \text { Tunisian } \\
\text { families }\end{array}$ & Hyper IgE syndrome & $\begin{array}{l}\text { Novel homozygous mutations in PGM3 } \\
\text { in } 2 \text { Tunisian families }\end{array}$ \\
\hline Ben-Mustapha ${ }^{[44]}(2014)$ & Tunisia & 6 Tunisian patients & MSMD & $\begin{array}{l}\text { Founder effect for the c.298_305del } \\
\text { mutation in the IL12B gene }\end{array}$ \\
\hline $\operatorname{Baba}^{[45]}(2014)$ & Morocco & 12 & CGD & $\begin{array}{l}\text { Four different mutations of } C Y B B \text {, a } \\
\text { recurrent mutation of } N C F 1 \text { and a new } \\
\text { mutation of NCF2 in three patients }\end{array}$ \\
\hline Ben-Mustapha et al. ${ }^{[46]}$ (2013) & Tunisia & $\begin{array}{l}34 \text { (belonging to } 28 \\
\text { Tunisian families) }\end{array}$ & $\begin{array}{l}\text { MHC class II expression } \\
\text { deficiency }\end{array}$ & $\begin{array}{l}\text { Founder effect for the c.338-25_338del } 26 \\
\text { mutation in the RFXANK gene in } 25 \\
\text { patients }\end{array}$ \\
\hline Landouré et al. ${ }^{[4]]}(2013)$ & Mali & $\begin{array}{l}3 \text { patients from } 1 \\
\text { Malian family }\end{array}$ & Ataxia-telangiectasia & $\begin{array}{l}\text { Novel c.7985T > A mutation in ATM } \\
\text { gene }\end{array}$ \\
\hline Djidjik et al. ${ }^{[48]}(2012)$ & Algeria & 11 Algerian patients & $\begin{array}{l}\text { MHC class II expression } \\
\text { deficiency }\end{array}$ & $\begin{array}{l}\text { Founder effect for the } 752 \text { delG } 26 \\
\text { mutation in RFXANK gene in } 9 \text { patients }\end{array}$ \\
\hline Naamane et al. ${ }^{[49]}(2010)$ & Morocco & 10 Moroccan patients & $\begin{array}{l}\text { MHC class II expression } \\
\text { deficiency }\end{array}$ & $\begin{array}{l}\text { Founder effect for the } 752 \text { delG } 26 \\
\text { mutation in the RFXANK gene in } 10 \\
\text { patients }\end{array}$ \\
\hline El Kares et al. ${ }^{[50]}(2006)$ & Tunisia & 15 Tunisian patients & CGD & $\begin{array}{l}\text { Two novel and recurrent mutations in } \\
\text { NCF2 and CYBA gene }\end{array}$ \\
\hline Pienaar et al. ${ }^{[51]}(2003)$ & SA & 2 SA patients & Hyper IgM & $\begin{array}{l}\text { First report of X-linked hyper IgM } \\
\text { (HIGM1) from SA }\end{array}$ \\
\hline Elloumi-Zghal et al. ${ }^{[52]}$ (2002) & Tunisia & 5 Tunisian patients & MSMD & $\begin{array}{l}I L-12 R b 1 \text { gene mutation in } 2 \text { patients } \\
\text { and } I L-12 p 40 \text { gene mutation in } \\
3 \text { patients; } \\
\text { first description of familial cytokine } \\
\text { deficiency }\end{array}$ \\
\hline Eley BS et al. ${ }^{[53]}(2001)$ & SA & 5 SA patients & SCID & $\begin{array}{l}3 \text { with IL-2R } \gamma \mathrm{C} \text { deficiency; } \\
1 \text { with RAG1 deficiency } \\
1 \text { with IL-7Ra deficiency }\end{array}$ \\
\hline Pienaar et al. ${ }^{[54]}(2000)$ & SA & 5 SA patients & $\begin{array}{l}\mathrm{X} \text {-linked } \\
\text { agammaglobulinaemia }\end{array}$ & Btk gene mutation \\
\hline
\end{tabular}


Table 5. (continued) Genetic studies on PID in Africa and elsewhere

\begin{tabular}{|c|c|c|c|c|}
\hline Study & $\begin{array}{l}\text { Country } \\
\text { where } \\
\text { study was } \\
\text { undertaken }\end{array}$ & $\begin{array}{l}\text { Patient number and } \\
\text { origin }\end{array}$ & PID studied & Genetic findings \\
\hline \multicolumn{5}{|l|}{ Studies from outside Africa } \\
\hline Ouederni et al..$^{[55]}(2011)$ & France & $\begin{array}{l}35 \text { North African } \\
\text { patients }\end{array}$ & $\begin{array}{l}\text { MHC class II expression } \\
\text { deficiency }\end{array}$ & $\begin{array}{l}\text { Founder effect for the } 752 \mathrm{delG} 26 \\
\text { mutation in the RFXANK gene in } 35 \\
\text { patients }\end{array}$ \\
\hline Boisson-Dupuis $^{[56]}(2011)$ & France & $\begin{array}{l}50 \text { patients from } \\
\text { Morocco, Iran and } \\
\text { Turkey }\end{array}$ & MSMD & $\begin{array}{l}\text { Homozygosity for loss-of-function } \\
\text { IL12RB1 alleles in } 2 \text { patients, } 1 \text { from } \\
\text { Morocco and the other from Iran }\end{array}$ \\
\hline $\begin{array}{l}\text { Lennon-Duménil et al }{ }^{[57]} \\
\text { (2001) }\end{array}$ & France & 1 North African patient & $\begin{array}{l}\text { MHC class II expression } \\
\text { deficiency }\end{array}$ & $\begin{array}{l}\text { Uncoordinated expression of the } H L A-D \\
\text { genes in a new RFXANK gene mutation }\end{array}$ \\
\hline Altare et al. ${ }^{[58]}(2001)$ & France & $\begin{array}{l}2 \text { siblings from North } \\
\text { Africa }\end{array}$ & MSMD & $\begin{array}{l}\text { Heterogeneity of the clinical phenotype } \\
\text { associated with IL-12RB1 deficiency }\end{array}$ \\
\hline Wiszniewski et al. ${ }^{[59]}(2000)$ & France & $\begin{array}{l}20 \text { North African } \\
\text { patients }\end{array}$ & $\begin{array}{l}\text { MHC class II expression } \\
\text { deficiency }\end{array}$ & $\begin{array}{l}\text { Founder effect for the } 752 \text { delG } 26 \\
\text { mutation in the RFXANK gene in } 17 \\
\text { patients }\end{array}$ \\
\hline Jouanguy et al..$^{[60]}$ (1996) & France & 1 Tunisian patient & MSMD & First report of INF $\gamma$ receptor deficiency \\
\hline
\end{tabular}

mutation for Mendelian susceptibility to mycobacterial disease (MSMD) arising 1 100 years ago.

There are additional scattered studies from the region describing PID, including patients' susceptibilities to various infections and case reports. ${ }^{[61-68]}$

\section{Diagnosis of PID on the African continent}

Although basic laboratory tests are available for the diagnosis of PID in some African countries, there are still limitations with regard to specialised immunological and genetic tools required for more accurate investigations. Particular laboratory tests, e.g. specific antibodies (IgG subclasses) lymphocyte subpopulations and proliferation studies, and functional phagocyte tests, are only available in a very limited number of referral centres.

With respect to molecular studies, many centres on the continent are in the early phases of development, with limited capacity for genetic diagnosis of some PIDs. There has been a recent drive in African referral centres to expand molecular diagnostic services for PID, which includes polymerase chain reaction (PCR) analysis of T-cell receptor excision circles (TREC) and Kappadeleting recombination excision circles (KREC) as part of a newborn screening programme for severe PIDs. Still, most centres work in collaboration with specialised laboratories abroad for occasional definitive diagnosis of selected PID cases.

In 2016, a private diagnostic laboratory in South Africa developed a targeted next-generation sequencing (NGS) gene panel consisting of 99 of the most frequently associated PID genes. ${ }^{[0]}$ The panel can be used as both a molecular confirmation and a screening tool for 18 PID phenotypes found within the nine International Union of Immunological Societies (IUIS) PID classifications (Table 1). Furthermore, whole exome and transcriptome sequencing are currently being investigated for those more challenging cases in which clinical presentation is indicative of a PID when immunological investigations and targeted sequencing have proved uninformative. Table 6 shows the laboratory tests available for the diagnosis of
PID in SA; these have been grouped into a stepwise investigative approach. All the tests indicated are available in SA and the public (government) sector has permission to refer this work to Ampath through the National Health Laboratory Services when clinically indicated. Lack of diagnostic facilities can cause delays in diagnosis and may ultimately compromise the clinical outcome of these patients. ${ }^{[33,34,36]}$

\section{Treatment options for PID in Africa}

With an average mortality rate of $20 \%$ in northern and southern Africa, there are still considerable challenges in the region regarding the management and overall clinical outcome of PID patients. ${ }^{[34-37]}$ Generally, $40 \%$ of PID patients in these regions receive intravenous immunoglobulin (IVIG ${ }^{[34,35,40]}$ despite limitations in the availability of IVIG in some regions. ${ }^{[33]}$

HSCT using haploidentical donors has been introduced as a treatment option in severe cases of PID but only in very few centres on the continent and with long waiting lists. ${ }^{[34-36]}$ However, due to the cost morbidity and mortality associated with HSCT, clinicians are very cautious about administering gene therapy, specifically if the patient is fairly well controlled.

\section{Gene therapy as an option in the African continent}

According to the JMF global survey, there has been a significant increase in the number of patients receiving gene therapy worldwide, with the greatest number residing in Western Europe. ${ }^{[10]}$ Although in 2016 the first retroviral long terminal repeat (LTR)-based vector received license for ex vivo gene therapy in SCID, many challenges still need to be overcome before gene therapy can be offered as a standard therapy for all patients. ${ }^{[76]}$ To our knowledge, no centre on the African continent has performed gene therapy on PID patients to date. As the field of PIDs continues to grow and the number of children and adults diagnosed with PID in the region increases, gene therapy could become an effective treatment option for patients on the African continent in the future. 
Table 6. A stepwise approach to the laboratory diagnosis of PID*

\begin{tabular}{|c|c|c|}
\hline & Test & Association \\
\hline \multirow[t]{7}{*}{ First-line investigations } & Exclude HIV & \\
\hline & Assessment for atopy & As indicated on history \\
\hline & Full blood count & Lymphopaenia is an important indicator of possible SCID \\
\hline & $\begin{array}{l}\text { - Differential count for neutrophil and } \\
\text { lymphocyte numbers } \\
\text { - Platelet count and morphology }\end{array}$ & Small platelets seen in WAS \\
\hline & - Serum Ig: G, M, A and E & $\begin{array}{l}\text { IgE should be tested in patients who may be at risk of } \\
\text { hyper IgE syndrome }\end{array}$ \\
\hline & - TRECs and KREC PCR & $\begin{array}{l}\text { Used for neonatal screening for SCID and XLA on blood } \\
\text { monospots - useful to do prior to giving live vaccines at } \\
\text { birth }\end{array}$ \\
\hline & - CF screening & Suspected on history and clinical examination \\
\hline \multirow[t]{9}{*}{ Second-line investigations } & IgG subclasses & IgG subclass deficiency and other immunodeficiencies \\
\hline & $\begin{array}{l}\text { Specific antibody response } \\
\text { - Pneumococcus and Haemophilus influenzae } \\
\text { (targeted to polysaccharide-specific antigens) } \\
\text { - Tetanus, diphtheria and H. influenzae (target } \\
\text { protein antigens) }\end{array}$ & $\begin{array}{l}\text { Indicated with recurrent bacterial infections even in } \\
\text { the presence of normal immunoglobulins. Patients have } \\
\text { to be off immunoglobulin replacement therapy for } 6 \\
\text { months. If these antibody levels are decreased, the patient } \\
\text { should be revaccinated and antibody responses should } \\
\text { be repeated } 4 \text { weeks after vaccine boosting to determine } \\
\text { an appropriate increase in specific antibody responses. } \\
\text { Note that an unconjugated pneumococcal vaccine, e.g. } \\
\text { Pneumovax, should be given to determine an appropriate } \\
\text { polysaccharide antigen response. }\end{array}$ \\
\hline & Lymphocyte subsets & Absent in XLA where all immunoglobulin isotypes are \\
\hline & - B cell numbers (CD19) & severely reduced \\
\hline & T cell numbers $(\mathrm{CD} 3)$ & Reduced in T cell defects combined immunodeficiencies \\
\hline & T helper (CD4) and T suppressor (CD8) & and occasionally CVID \\
\hline & NK cells (CD16 and CD56) & $\begin{array}{l}\text { Isolated NK-cell deficiencies may be associated with } \\
\text { recurrent herpes virus infections }\end{array}$ \\
\hline & Neutrophil function & \\
\hline & - Neutrophil oxidative burst & CGD \\
\hline \multirow[t]{11}{*}{ Third-line investigations } & $\begin{array}{l}\text { Lymphocyte proliferation studies } \\
\text { - Response to mitogens e.g. } \\
\text { phytohaemagglutinin PMA PMA +ionomycin } \\
\text { anti-CD3 anti-CD3+IL2 } \\
\text { - Response to recall antigens e.g. Candida, } \\
\text { tetanus, varicella-zoster virus }\end{array}$ & $\begin{array}{l}\text { T cell deficiencies including SCID, chronic mucocutaneous } \\
\text { candidiasis }\end{array}$ \\
\hline & Neutrophil antibodies & Alloimmune and autoimmune neutropaenia \\
\hline & T cell maturation panel: Naïve and memory T cells & Diagnosis of SCID and combined T cell defects \\
\hline & Recent thymic emigrants ( $\mathrm{T}$ cells) & Very low in SCID \\
\hline & & $\begin{array}{l}\text { Can be used to monitor bone marrow regeneration post } \\
\text { transplant }\end{array}$ \\
\hline & Memory B cells & $\begin{array}{l}\text { Memory B cells categorise subsets of CVID patients and } \\
\text { are decreased in X-linked HIGM }\end{array}$ \\
\hline & Alpha/beta/gamma/delta $\mathrm{T}$ cell receptor type & $\begin{array}{l}\text { Abnormal in leaky SCID, hypomorphic SCID T cell defects } \\
\text { with oligoclonality }\end{array}$ \\
\hline & Total haemolytic complement & Complement deficiencies \\
\hline & - Classic & Patient may suffer from recurrent URTIs and may have \\
\hline & - Alternative & a higher risk for severe meningococcal or pneumococcal \\
\hline & Mannan binding lectin (MBL) & infections. \\
\hline \multirow[t]{3}{*}{ Fourth-line investigations } & - Genetic testing & $\begin{array}{l}\text { Various PID panels available or exome sequencing as } \\
\text { clinically indicated }\end{array}$ \\
\hline & - Complement studies & To be discussed with clinical immunologist \\
\hline & - Confirmatory test & \\
\hline \multicolumn{3}{|c|}{$\begin{array}{l}\text { PID = primary immunodeficiency; } \mathrm{HIV}=\text { human immunodeficiency virus; } \mathrm{SCID}=\text { severe combined immunodeficiency; WAS }=\text { Wiskott-Aldrich syndrome; } \mathrm{Ig}=\text { immunoglobulin; } \\
\mathrm{TREC}=\mathrm{T} \text { cell receptor excision circles; KREC }=\text { Kappa receptor excision circles; } \mathrm{PCR}=\text { polymerase chain reaction; } \mathrm{XLA}=\mathrm{X} \text {-linked agammaglobulinaemia; } \mathrm{CF}=\text { cystic fibrosis; } \mathrm{CD} 3=\text { cluster of } \\
\text { differentiation } 3 ; \mathrm{CVID}=\text { common variable immune deficiency; } \mathrm{NK}=\text { natural killer; } \mathrm{CGD}=\text { chronic granulomatous disease; } \mathrm{PMA}=\text { phorbol myristate acetate; } \mathrm{IL}=\text { interleukin; } \mathrm{URTI}=\text { upper } \\
\text { respiratory tract infections; } \mathrm{MBL}=\text { mannan-binding lectin. }\end{array}$} \\
\hline
\end{tabular}


In addition to the outcomes and efficacy of this form of treatment, elevated costs are a major concern. However, many believe that a onetime cure could still save money in the long-term by reducing the need for expensive care. In 2014, Buckland et al. ${ }^{[69]}$ reported that the cost of an allogeneic bone marrow transplant for a patient with a primary immunodeficiency was $\geq £ 250000$. In contrast, the manufacture of autologous gene modified $\mathrm{CD} 34^{+}$cells could be achieved at a cost of $\sim £ 15000$ - $£ 30000$. The additional follow-up costs after gene therapy treatment for PIDs are also likely to be significantly less given that the length of hospital stay and long-term prophylactic medication requirements and other post-therapy complications are considerably reduced, compared with conventional HSCT.

\section{Limitations regarding PID on the African continent}

PID is mostly underdiagnosed in Africa and, although considerable progress has been achieved in parts of the continent, many challenges remain regarding awareness, diagnosis, registration and care of these patients.

At present, only 2 of the 54 countries on the continent have national registries: the Moroccan Society for PID (MSPID, www.pidmoroccansociety.org) and the South African National PID Registry (https://www.pinsa.org.za/). Without national registries, accurate prevalence and incidence data cannot be gathered. Participation in these networks will establish earlier diagnosis and improve treatment and clinical care, resulting in an improvement in the quality of life of these patients. There is also a need to improve public health policy in this field. ${ }^{[6,33]}$

The lack of specialised physicians in the field of clinical immunology in many areas of the African continent negatively affects the management of PID patients in the region. The training of expert clinical immunologists could assist in raising awareness of PID in the medical community. In addition, networks such as Primary Immunodeficiency Diseases Network of South Africa (PINSA) and ASID could play an important role in creating awareness of PIDs on the continent.

The burden of HIV and other epidemic illnesses, particularly in the sub-Saharan region, is likely to be a major contributor to the under-diagnosis of PID. ${ }^{[28]}$ It is assumed that the expanding HIV epidemic, especially in SA, over the past 30 years has compromised clinical recognition of PID. ${ }^{[34]}$

In addition to efforts aimed at increasing the awareness of PID in the region, there is a need for improvement in diagnosis. Conducting molecular and genetic studies in the region could support the future development of genetic counseling, prenatal diagnosis and gene therapy. ${ }^{[33]}$

Africa faces a number of challenges, which include a paucity of diagnostic facilities, limited expertise, as well as limited financial resources. These challenges may be overcome by creating diagnostic referral centers for PID on the continent. These specialised centres could potentially offer basic as well as definitive molecular diagnostic services at a lower cost and faster turnaround time than when samples are sent to international laboratories.

\section{Conclusion}

With the exception of South and northern Africa, there appears to be limited activity in the field of PID on the African continent, resulting in lack of awareness, underdiagnoses, mismanagement and suboptimal care. Additionally, as the field of PID is continually growing, advanced therapeutic modalities are rapidly expanding worldwide and options such as gene therapy are becoming a reality.
Given the unique genetic mutations reported in PID patients on the African continent and the feasibility of HSCT and gene therapy, these new therapeutic options should be considered.

Acknowledgements. We would like to thank Professor Ronnie Anderson for his constructive comments.

Author contributions. AE: Study conception and design, drafting and writing of the paper; MB: interpretation of data and co-writing the paper; CvR: co-writing and revision of the paper; SvdB: co-writing and revision of the paper; CJK: co-writing and revision of the paper; RJG: critical revision; MSP: study conception and design, supervision, critical revision of the paper, funding.

Funding. This research, and the publication thereof, is the result of funding provided by the Medical Research Council of South Africa in terms of the MRC's Flagships Awards Project SAMRC-RFA-UFSP-01-2013/STEM CELLS the SAMRC Extramural Unit for Stem Cell Research and Therapy and the Institute for Cellular and Molecular Medicine of the University of Pretoria.

Conflicts of interest. None.

1. De Vries E, European Society for Immunodeficiencies (ESID) members. Patient-centred screening for primary immunodeficiency, a multi-stage diagnostic protocol designed for non-immunologists: 2011 update. Clin Exp Immunol 2012;167(1):108-119. https://doi.org/10.1111/j.1365-2249.2011.04461.x

. Lehman H, Hernandez-Trujillo V, Ballow M. Brief review. Diagnosing primary immunodeficiency: A practical approach for the non-immunologist. Curr Med Res Opin 2015;31(4):697-706. https://doi.or $\mathrm{g} / 10.1185 / 03007995.2014 .1001063$

3. Seymour B, Miles J, Haeney M. Primary antibody deficiency and diagnostic delay. J Clin Pathol 2005;58(5):546-547. https://doi.org/10.1136/jcp.2004.016204

4. Kobrynski L, Powell RW, Bowen S. Prevalence and morbidity of primary immunodeficiency diseases, United States 2001-2007. J Clin Immunol. 2014;34(8):954-961. https://doi.org/10.1007/s10875-014United

5. Picard C, Al-Herz W, Bousfiha A, et al. Primary immuno-deficiency diseases: An update on the classification from the International Union of Immunological Societies Expert Committee for Primary Immunodeficiency 2015. J Clin Immunol 2015:1-31. https://doi.org/ 10.1007/s10875-015-0201-1

6. Bousfiha AA, Jeddane L, Ailal F, et al. Primary immunodeficiency diseases worldwide: More common than generally thought. J Clin Immunol. 2013;33(1):1-7. https://doi.org/10.1007/s10875-012-9751-7 Kirkpatrick P, Riminton S. Primary immunodeficiency diseases in Australia and New Zealand. J Clin Immunol 2007;27(5):517-524. https://doi.org/10.1007/s10875-007-9105-z)

8. Boyle JM Buckley RH. Population prevalence of diagnosed primary immunodeficiency diseases in the United States. J Clin Immunol 2007;27:497-502. https://doi.org/ 10.1007/s10875-007-9103-1

9. Joshi AY, Iyer VN, Hagan JB, St. Sauver JL, Boyce TG. Incidence and temporal trends of primary immunodeficiency: A population-based cohort study. Mayo Clin Proc 2009;84(1):16-22. https://doi. org/10.4065/84.1.16

10. Modell V, Orange JS, Quinn J, Modell F. Global report on primary immunodeficiencies: 2018 update from the Jeffrey Modell Centers Network on disease classification, regional trends, treatment update from the Jeffrey Modell Centers Network on disease classification, regional trends, treatment
modalities and physician reported outcomes. Immun Res 2018;66(3):367-380. https://doi.org/10.1007/ modalities and phys

11. Baumgart KW, Britton WJ, Kemp A, French M, Roberton D. The spectrum of primary immunodeficiency disorders in Australia. J Allergy Clin Immunol 1997;100(3):415-423. https://doi. org/10.1016/S0091-6749(97)70257-4

12. Stray-Pedersen A, Abrahamsen TG, Frøland SS. Primary immunodeficiency diseases in Norway. J Clin Immunol 2000;20(6):477-485. https://doi.org/10.1023/A:1026416017763

13. Aghamohammadi A, Mohammadinejad P, Abolhassani H, et al. Primary immunodeficiency disorders in Iran: Update and new insights from the third report of the national registry. J Clin Immunol 2014;34(4):478-490. https://doi.org/10.1007/s10875-014-0001-z

14. De Vries E, Driessen G. Educational paper primary immunodeficiencies in children: A diagnostic challenge. Eur J Pediatr 2011;170:169-177. https://doi.org/ 10.1007/s00431-010-1358-5

15. Bousfiha A, Jeddane L, Al-Herz W, et al. The 2015 IUIS Phenotypic Classification for Primary Immunodeficiencies. J Clin Immunol 2015;35(8):727-738. https://doi.org/10.1007/s10875-015-0198-5

16. Ochs HD Hagin D. Primary immunodeficiency disorders: General classification, new molecular insights and practical approach to diagnosis and treatment. Ann Allergy Asthma Immunol
inter insights and practical approach to diagnosis and treatment.
2014;112(6):489-495. https://doi.org/ 10.1016/.anai.2014.04.00

17. Latif AH, Tabassomi F, Abolhassani H, Hammarström L. Molecular diagnosis of primary Latif AH, Tabassomi F, Abolhassani H, Hammarström L. Molecular diagnosis of primary
immunodeficiency diseases in a developing country: Iran as an example. Expert Rev Clin Immunol immunodeficiency diseases in a developing country: Iran as an ex

18. Condino-Neto A, Franco JL, Trujillo-Vargas C ,et al. Critical issues and needs in management of primary immunodeficiency diseases in Latin America. Allergol Immunopathol 2001;39:45-51. https:// doi.org/10.1016/j.aller.2010.09.001

19. Fischer A, Hacein-Bey-Abina S, Cavazanna-Calvo M. Gene therapy for primary immunodeficiencies. Immunol Allergy Clin North A 2010;30(2):237-248. https://doi.org/ 10.1016/j.iac.2010.02.002)

20. Busse PJ, Razvi S, Cunningham-Rundles C. Efficacy of intravenous immunoglobulin in the prevention of pneumonia in patients with common variable immunodeficiency. J Allergy Clin Immunol 2002;109(6):1001-1004. https://doi.org/10.1067/mai.2002.124999

21. Lucas M, Lee M, Lortan J, Lopez-Granados E, Misbah S, Chapel H. Infection outcomes in patients with common variable immunodeficiency disorders: Relationship to immunoglobulin therapy over 22 years. J Allergy Clin Immunol 2010;125(6):1354-1360.e4. https://doi.org/ 10.1016/j.jaci.2010.02.040

2. Ballow M. Primary immunodeficiency disorders: Antibody deficiency. J Allergy Clin Immunol 2012;109(4):581-591. https://doi.org/10.1067/mai.2002.122466

23. Griffith LM, Cowan MJ, Notarangelo LD, et al. Improving cellular therapy for primary immune deficiency diseases: Recognition, diagnosis and management. J Allergy Clin Immunol 2009;124(6):1152-1160.e12. https://doi.org/ 10.1016/j.jaci.2009.10.022 
24. Gennery AR, Slatter MA, Grandin L, Taupin P, Inborn Errors Working Party of the European Group for Blood and Marrow Transplantation, European Society for Immunodeficiency. Transplantation of hematopoietic stem cells and long-term survival for primary immunodeficiencies in Europe: Entering hematopoietic stem cells and long-term survival for primary immunodeficiencies in Europe: Entering
a new century do we do better? I Allergy Clin Immunol 2010;126:602. https:// doi.org/ 10.1016/j. a new century
jaci.2010.06.015

25. Gatti RA, Meuwissen HJ, Allen HD, Hong R, Good RA. Immunological reconstitution of sex-linked lymphopenic immunological deficiency. Lancet 1968;2(7583):1366-1369. https://doi.org/10.1016/ S0140-6736(68)92673-1

26. De la Morena MT, Nelson RP Jr. Recent advances in transplantation for primary immune deficiency diseases: A comprehensive review. Clin Rev Allerg Immunol 2014;46(2):131-144. https://doi.org/ $10.1007 /$ s12016-013-8379-6

27. Neven B, Leroy S, Decaluwe H, et al. Long-term outcome after haematopoietic stem cell transplantation of a single-centre cohort of 90 patients with severe combined immunodeficiency: Long-term outcome of HSCT in SCID. Blood 2009;113(17):4114-4124. https://doi.org10.1182/blood-2008-09-177923

28. Blaese RM, Culver KW, Miller AD, et al. Tlymphocyte-directed gene therapy for ADA-SCID: Initial trial results after 4 years. Science 1995;270(5235):475-480. https://doi.org/ 10.1126/science.270.5235.475

29. Bordignon C, Notarangelo LD, Nobili N, et al. Gene therapy in peripheral blood lymphocytes and bone marrow for ADA-immunodeficient patients. Science 1995;270(5235):470-475. https://doi. bone marrow for ADA-immuno
org $/ 10.1126 /$ science. 270.5235 .470

30. Aiuti A, Roncarolo MG. Ten years of gene therapy for primary immune deficiencies. Hematology Am Soc Hematol Educ Program 2009:682-689. https://doi.org/10.1182/asheducation-2009.1.682

31. Baum C. Insertional mutagenesis in gene therapy and stem cell biology. Curr Opin Hematol 2007;14(4):337-342. https://doi.org/10.1097/MOH.0b013e3281900fo

32. Sorensen R, Etzioni A, Bousfiha AA, Zeiger JB. Collaborating to improve quality of life in primary immunodeficiencies: World PI Week, 2013. J Clin Immunol 2013;33(7):1145-1148. https://doi. org/10.1007/s10875-013-9921-2

33. Barbouche MR, Galal N, Ben-Mustapha I, et al. Primary immunodeficiencies in highly consanguineous North African populations. Ann N Y Acad Sci 2011;1238(1):42-52. https://doi.org/10.1111/j.17496632.2011.06260.x

34. Naidoo R, Ungerer L, Cooper M, Pienaar S, Eley BS. Primary immunodeficiencies: A 27-year review at a tertiary paediatric hospital in Cape Town, South Africa. J Clin Immunol 2011;31(1):99-105. https:// doi.org/10.1007/s10875-010-9465-7

35. Reda SM, Afifi HM, Amine MM. Primary immunodeficiency diseases in Egyptian children: A singlecenter study. J Clin Immunol 2009;29(3):343-351. https://doi.org/10.1007/s10875-008-9260-x

36. Bousfiha AA, Jeddane L, EL Hafidi N, et al. First report on the Moroccan registry of primary immunodeficiencies: 15 years of experience (1998 - 2012). J Clin Immunol 2014;34(4):459-68. https://
immorits doi.org/10.1007/s10875-014-0005-8

37. Bejaoui M, Barbouche MR, Sassi A, et al. [Primary immunodeficiency in Tunisia: Study of 152 cases]. Arch Pediatr 1997;4(9):827-831. https://doi.org/ 10.1016/S0929-693X(97)88145-6

38. Mellouli F, Mustapha I Ben, Khaled M Ben, et al. Report of the Tunisian registry of primary immunodeficiencies: 25 years of experience (1988 - 2012). J Clin Immunol 2015;35(8):745-753. https:// doi.org/10.1007/s10875-015-0206-9

39. Eley BS, Hughes J, Cooper M, Pienaar S, Beatty DW. Primary immunodeficiency diseases at Red Cross War Memorial Children's Hospital. South African Med J. 1997;87(12):1684-1688.

40. Esser M, Esser M. Primary immunodeficiency - missed opportunities and treatment challenges: Review article. Curr Allergy Clin Immunol 2012;25(4):184-188.

41. Owen EP, Würzner R, Leisegang F, et al. A complement C5 gene mutation, c.754G>A:p.A252T, is common in the Western Cape, South Africa and found to be homozygous in seven percent of Black African meningococcal disease cases. Mol Immunol 2015;64(1):170-176. https://doi.org/10.1016/j. African meningococcal
molimm.2014.11.010

42. Jlajla H, Sellami MK, Sfar I, et al. New Clq mutation in a Tunisian family. Immunobiology 2014;219(3):241-246. https://doi.org/10.1016/ji.imbio.2013.10.010

43. Sassi A, Lazaroski S, Wu G, et al. Hypomorphic homozygous mutations in phosphoglucomutase 3 (PGM3) impair immunity and increase serum IgE levels. J Allergy Clin Immunol 2014;133(5):14101419. https://doi.org/10.1016/j.jaci.2014.02.025

44. Ben-Mustapha I, Ben-Ali M, Mekki N, et al. A 1,100-year-old founder effect mutation in IL12B gene is responsible for Mendelian susceptibility to mycobacterial disease in Tunisian patients. Immunogenetics 2014;66(1):67-71. https://doi.org/10.1007/s00251-013-0739-0

45. Baba LA, Ailal F, El Hafidi N, et al. Chronic granulomatous disease in Morocco: Genetic, immunological, and clinical features of 12 patients from 10 kindreds. J Clin Immunol. 2014;34(4):452458. https://doi.org/10.1007/s10875-014-9997-3

46. BenMustapha-Darghouth I, Trabelsi S, Largueche B, Bejaoui M, Dellagi K, Barbouche M-R. [Prevalence of Pneumocystis jiroveci pneumonia in Tunisian primary immunodeficient patients]. Arch Pediatr 2007;14(1):20-23. https://doi.org/10.1016/j.arcped.2006.10.012

47. Landouré G, Mochel F, Meilleur K, et al. Novel mutation in the ATM gene in a Malian family with .
ataxia telangiectasia. J Neurol 2013;260(1):324-326. https:// / 0 oi.org/10.1007/s00415-012-6738-5

48. Djidjik R, Messaoudani N, Tahiat A, et al. Clinical, immunological and genetic features in eleven

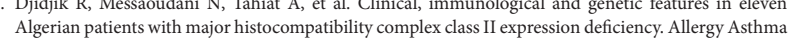
Clin Immunol 2012;8(1):14 https://doi.org/10.1186/1710-1492-8-14

49. Naamane H, El Maataoui O, Ailal F, et al. The 752 delG26 mutation in the RFXANK gene associated with major histocompatibility complex class II deficiency: Evidence for a founder effect in the Moroccan population. Eur J Pediatr 2010;169(9):1069-1074. https://doi.org/10.1007/s00431-010-1179-6
50. El Kares R, Barbouche MR, Elloumi-Zghal H, et al. Genetic and mutational heterogeneity of autosomal recessive chronic granulomatous disease in Tunisia. J Hum Genet 2006;51(10):887-895. https://doi org/10.1007/s10038-006-0039-8

51. Pienaar S, Eley BS, Hughes J, Henderson HE. X-linked Hyper IgM (HIGM1) in an African kindred: The first report from South Africa. BMC Pediatr 2003;3(12). https://doi.org/10.1186/1471-2431-3-12

52. Elloumi-Zghal H, Barbouche MR, Chemli J, et al. Clinical and genetic heterogeneity of inherited autosomal recessive susceptibility to disseminated Mycobacterium bovis Bacille Calmette-Guérin infection. J Infect Dis 2002;185(10):1468-1475. https://doi.org/10.1086/340510

53. Eley B, Beatty D. Primary immunodeficiency diseases in Cape Town. Allergy Clin Immunol Int World Allergy Organ 2006;12(6):0267-0270

54. Pienaar S, Eley B, Beatty DW, Henderson HE. X-linked agammaglobulinaemia and the underlying genetics in two kindreds. J Paediatr Child Health 2000;36(5):453-456. https://doi.org/10.1046/j.14401754.2000.00546.x

55. Ouederni M, Vincent QB, Frange P, et al. Major histocompatibility complex class II expression deficiency caused by a RFXANK founder mutation: A survey of 35 patients. Blood 2011;118(19):51085118. https://doi.org/10.1182/blood-2011-05-352716

56. Boisson-Dupuis S, Baghdadi JE, Parvaneh N, et al. Il-12r $\beta 1$ deficiency in two of fifty children with severe tuberculosis from IRN, MAR, and TUR. PLoS One 2011;6(4). https://doi.org/10.1371/journal. pone.0018524

57. Lennon-Duménil AM, Barbouche MR, Vedrenne J, et al. Uncoordinated HLA-D gene expression in RFXANK-defective patient with MHC class II deficiency. J Immunol 2001;166(9):5681-5687. https:// doi.org/10.4049/jimmunol.166.9.5681

58. Ensser A, Breiman A, Reichenbach J, Baghdadi J El, Fischer A. Interleukin-12 receptor B1 deficiency in a patient with abdominal tuberculosis. J Infect Dis 2001;184(2):231-236. https://doi.org $10.1086 / 321999$

59. Wiszniewski W, Fondaneche MC, Lambert N, et al. Founder effect for a 26-bp deletion in the RFXANK gene in North African major histocompatibility complex class II-deficient patients belonging to complementation group B. Immunogenetics 2000;51(4-5):261-267. https://doi.org/10.1007/ s002510050619

60. Jouanguy E, Altare F, Lamhamedi S, et al. Interferon-gamma-receptor deficiency in an infant with fatal Baccile Calmette-Guerin infection. N Engl J Med 1996;335(26):1956-1961. https://doi.org/ 10.1056/ NEJM199612263352604

61. Ben Abda I, Essid R, Mellouli F, Aoun K, Bejaoui M, Bouratbine A. Cryptosporidium infection in patients with major histocompatibility complex class II deficiency syndrome in Tunisia: description of five cases. Arch Pediatr 2011;18(9):939-944. https://doi.org/10.1016/j.arcped.2011.06.015

62. Driss N, Ben-Mustapha I, Mellouli F, et al. High susceptibility for enterovirus infection and virus excretion features in Tunisian patients with primary immunodeficiencies. Clin Vaccine Immuno 2012;19(10):1684-1689. https://doi.org/10.1128/cvi.00293-12

63. Hossny E, El-Awady H, El-Feky M, El-Owaidy R. Screening for B- and T-cell defects in Egyptian infants and children with suspected primary immunodeficiency. Med Sci Monit 2009;15(5):217-225 https://doi.org/10.1016/j.jaci.2007.12.341

64. Walong E, Rogena E, Sabai D. Primary immunodeficiency diagnosed at autopsy: A case report. BMC Res Notes. 2014;7(1):425. https://doi.org/10.1186/1756-0500-7-425

65. 66.Gumede N, Muthambi V, Schoub BD. Immunodeficiency-associated vaccine-derived poliovirus type 3 in infant, South Africa, 2011. Emerg Infect Dis 2012;18(6):992-994. https://doi.org/10.3201/ eid1806.120037

66. Bejaoui M, Barbouche MR, Mellouli F, Tirellil N, Dellagi K. [Agammaglobulinemia with absence of circulating B lymphocytes: A series of 9 cases] Press Medicale 1998;27(12):562-566.

67. Bejaoui M, Mellouli F, Chouanine R, Dellagi K, Barbouche MR. [The hyper-IgM syndrome: 13 observations]. Presse Medicale 2003;32(12):544-549.

68. Buckland KF, Bobby Gaspar H. Gene and cell therapy for children - new medicines, new challenges? Adv Drug Deliv Rev 2014;73:162-169. https://doi.org/10.1016/j.addr.2014.02.010

69. Van den Berg S, van Rooyen C, Green RJ. We can do more to identify patients with primary immunodeficiencies. Curr Allergy Clin Immunol 2017;30(1):44-52

70. Glanzmann B, Möller M, Moncada-Velez M, et al. Autosomal dominant IFN- $\gamma$ RI deficiency presenting with both atypical mycobacteriosis and tuberculosis in a BCG-vaccinated South African patient. J Clin Immunol 2018;38(4):460-463. https://doi.org/10.1007/s10875-018-0509-8

71. Glanzmann B, Abraham DR, Möller M, et al. Variable expression in SAMHD1-associated familia Aicardi-Goutières Syndrome. Curr Allergy Clin Immunol 2018;31(4):194-198.

72. Schlechter N, Glanzmann B, Hoal EG, et al. Exome sequencing identifies a novel MAP3K14 mutation in recessive atypical combined immunodeficiency. Front Immunol 2017;8:1624. https://dol. org/10.3389/fimmu.2017.01624

73. Kinnear C, Glanzmann B, Banda E, et al. Exome sequencing identifies a novel TTC37 mutation in the first reported case of Trichohepatoenteric syndrome (THE-S) in South Africa. BMC Med Genet 2017;18(1):26. https://doi.org/10.1186/s12881-017-0388-5

74. Glanzmann B, de Villiers N, Mölle M, et al. A primary immunodeficiency diseases odyssey - answe from the exome in a case with immunodeficiency and autoimmunity. Curr Allergy Clin Immuno 2017;30(4):134-139.

75. Thrasher AJ, Williams DA. Evolving Gene Therapy in Primary Immunodeficiency. Mol Ther 2017;25(5):1132-1141. https://doi.org/10.1016/j.ymthe.2017.03.018

76. Suchard M, Buldeo S, Van Rooyen C. Appropriate investigation of immunodeficiencies in Sout Africa. Curr Allergy Clin Immunol 2012;25(4):190-197. 